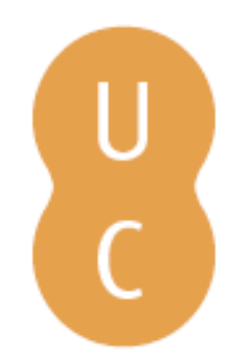

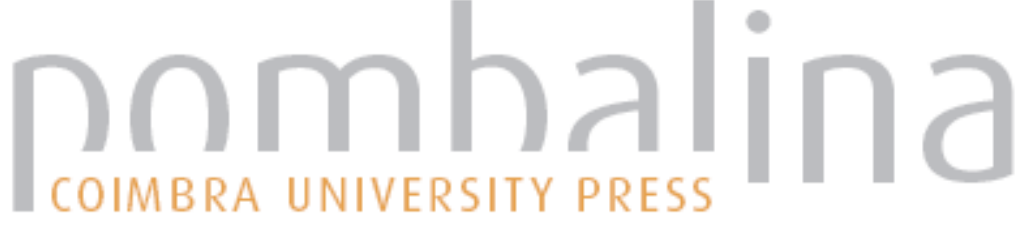

\section{Gil Vicente in english translation}
Autor(es): $\quad$ Baubeta, Patricia Odber de
Publicado por: Imprensa da Universidade de Coimbra
URL persistente:
URI:http://hdl.handle.net/10316.2/47477
DOI:
DOl:https://doi.org/10.14195/978-989-26-1548-6_15

Accessed : $\quad$ 26-Apr-2023 16:10:25

A navegação consulta e descarregamento dos títulos inseridos nas Bibliotecas Digitais UC Digitalis, UC Pombalina e UC Impactum, pressupõem a aceitação plena e sem reservas dos Termos e Condições de Uso destas Bibliotecas Digitais, disponíveis em https://digitalis.uc.pt/pt-pt/termos.

Conforme exposto nos referidos Termos e Condições de Uso, o descarregamento de títulos de acesso restrito requer uma licença válida de autorização devendo o utilizador aceder ao(s) documento(s) a partir de um endereço de IP da instituição detentora da supramencionada licença.

Ao utilizador é apenas permitido o descarregamento para uso pessoal, pelo que o emprego do(s) título(s) descarregado(s) para outro fim, designadamente comercial, carece de autorização do respetivo autor ou editor da obra.

Na medida em que todas as obras da UC Digitalis se encontram protegidas pelo Código do Direito de Autor e Direitos Conexos e demais legislação aplicável, toda a cópia, parcial ou total, deste documento, nos casos em que é legalmente admitida, deverá conter ou fazer-se acompanhar por este aviso.

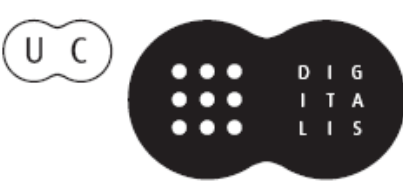



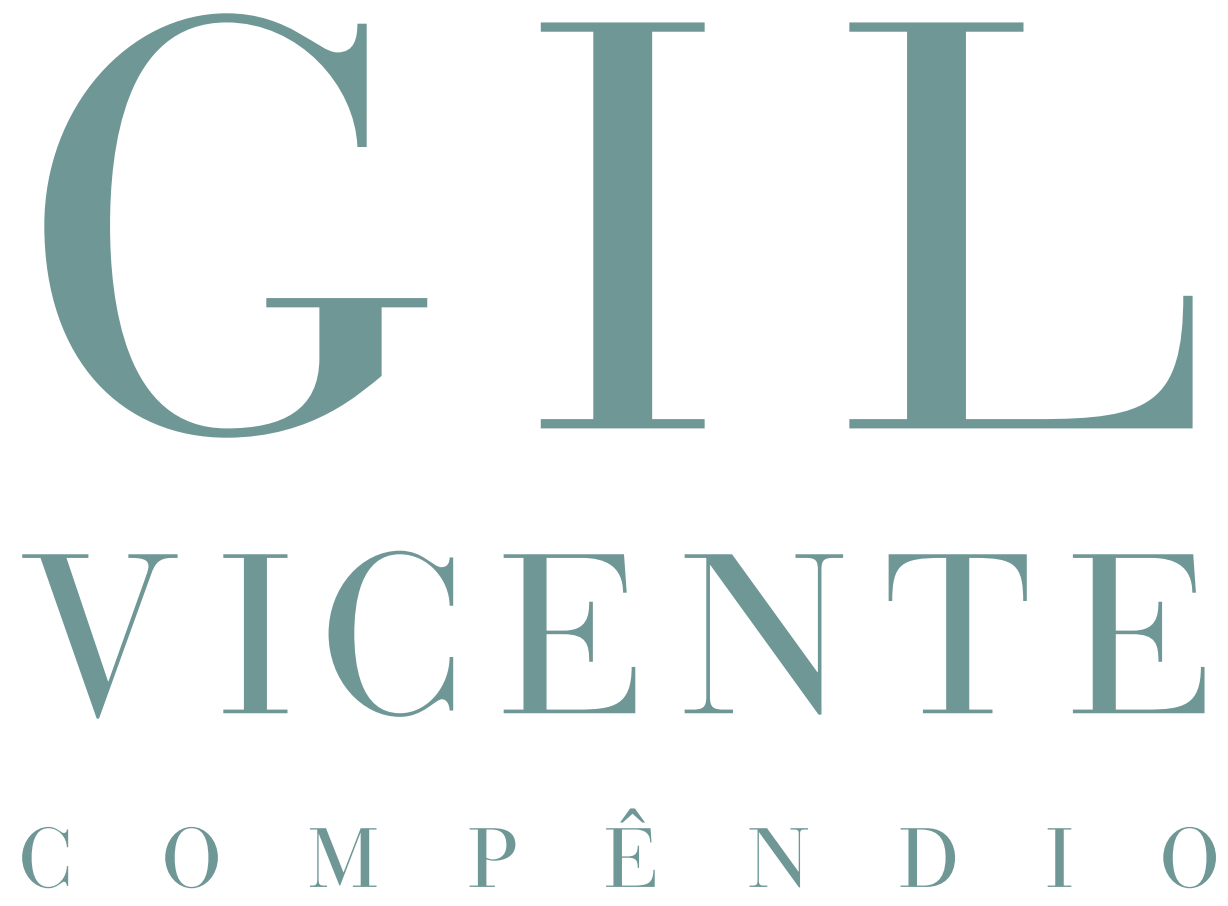

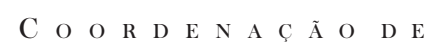

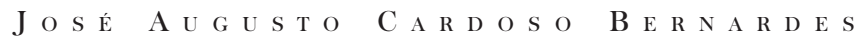

E J O S É C A M Õ E S

CoimbraCompanions

IVPRENSA DA UNIVERSIDADE DE COIMBRA

COIMBRA UNIVERSITY PRESS

IMPRENSA NACIONAL 


\section{Gil Vicente \\ in english translation}

Patricia Odber de Baubeta

UNIVERSITY OF BIRMINGHAM 
(Página deixada propositadamente em branco) 
The name Gil Vicente first appeared in English-language publications in 1823, when Thomasina Ross published her translation of Bouterwek's History of Spanish and Portuguese Literature and Thomas Roscoe published his English version of Sismondi's Historical View of the Literature of the South of Europe, which included extracts in English from the Auto da Feira. Vicente's works are next mentioned in a lengthy review of the Obras 1863 under the heading 'Ancient Portuguese Drama', published in the Quarterly Review of 1846. The anonymous author comments on selected plays and includes a number of lyrics and excerpts with accompanying English translations. Given that the first printing of the Copilaçam was in 1562, followed by the edition revised by the Inquisition in 1586 and since there was not another edition of the complete works until Barreto Feio and Gomes Monteiro's Obras Completas, Hamburg, 1834, it is hardly surprising that Gil Vicente did not become widely known, let alone available to translators until the nineteenth century. The interval between composition/performance and translation into English was therefore some three centuries. And yet, since the nineteenth century, at least 63 individuals have translated works by Gil Vicente, publishing their translations in academic journals, poetry magazines, play collections, histories of literature, anthologies or for musical performance. ${ }^{1}$ Quantifying the number of translations is more

1 Anonymous (Fraser's Magazine, 1831); anonymous (Quarterly Review, 1846); Arney, Ann Adele, Barnstone, Willis; Barter, A. R.; A Bell, Aubrey Fitz Gerald; Bernhoff, John; Blake, Mrs Euphemia Vale; Booty, Jill; Bowra, Sir Cecil Maurice; Bowring, John; Brenan, Gerald; Butler, 
problematic, since the translations range from single stanzas, poems, extracts and abridged versions to complete plays. Several plays even exist in multiple translations. We should not, however, overlook the frequency with which Gil Vicente's lyrics, claimed by Hispanists for their own, appear in Histories of Spanish Literature and anthologies (monolingual and bilingual); it is difficult to find an anthology of Spanish poetry for English-speaking readers that does not include Gil Vicente.

If 1823 is the terminus a quo for Vicentine translations, the first complete lyrics to be published as 'stand-alone' poems appear in Sir John Bowring's Ancient Poetry and Romances of Spain one year later. ${ }^{2}$ This remarkable work constitutes one of the earliest English anthologies of lyrics composed by Spanish and Portuguese poets, and received very favourable reviews from Mary Shelley, among others (Odber de Baubeta, 2008: 559-566). Note the Keatsian echoes of the titles that Bowring gave some of the poems: for example, 'En la huerta nasce la rosa' becomes 'The Nightingale'. ${ }^{3}$ Subsequent translators have imprinted their own ethnicity or literary tastes on the translations: both Aubrey Bell and Margaret Winefride Simpson and have rendered Vicentine lyrics into Scots: ${ }^{4}$

Eugene S.; Campbell, Roy; Cardona-Hine, Álvaro; Cleverley, Graham; Cranston, Philip; Cohen, J. M.; Cole, Brian; Craig, K. S.; Crow, John; Davis, William Myron; Dixon, Graham; Dykes, George; Fraser, Norman; Gallop, Rodney; Hervey, Charles; Jacoby, Grover I.; Johnston, David; Jeffs, Kathleen; King, Georgiana Goddard; Lappin, Anthony; Livermore, Ann; Longfellow, Henry Wadsworth; McCarthy, Denis Florence; MacLaren, Ann; McGinniss, Cheryl Folkins; McVan, Alice Jane; Parham, Charles J.; Peers, E. Allison; Potter, Robert; Power, Sheila Mary; Prestage, Edgar; Proske, Beatrice Gilman; Reckert, Stephen; Reid, John Howard; Resnick, Seymour; Rooney, Terry; Roscoe, Thomas; Serrano, Juan \& Serrano, Susan; Simpson, Margaret Winefride; Smolen, Marian Leanna; Smythe, David K.; Thomas, H. C.; Thornton, Seth G.; Ticknor, George; Tomlins, Jack E.; Trask, Willard Ropes; Trend, John Brande; Turnbull, Eleanor L.; Walsh, Thomas; Williams, Frederick G.; Young, George. (Information from this author's database).

2 'Muy graciosa es la doncella', Auto da la Sibila Casandra; 'En la huerta nasce la rosa', Auto dos Quatro Tempos; 'Del rosal vengo, mi madre', Triunfo do Inverno; 'Si dormís, doncella', Quem Tem farelos?; 'Mal haya quien los envuelve', Auto dos Quatro Tempos; 'Sañosa está la niña', Auto de la Sibila Casandra; ¿Cúal es la niña / que coge las flores?', O Velho da Horta.

3 See P. A. Odber de Baubeta, 'A Poem for all Seasons', in Rhian Davies and Anny Brooksbank-Jones (eds.), The Place of Argument. Essays in Honour of Nicholas Round. London: Tamesis, 2007, pp. 161-178.

4 See P. A. Odber de Baubeta, 'A Vicentine Canon in Translation: The Celtic Connection', in Aires A. Nascimento, Helena C. Langrouva, José V. de Pina Martins and Thomas F. Earle (eds.), Humanismo para o Nosso Tempo. Estudos de Homenagem a Luís de Sousa Rebelo. Lisboa: Edição Patrocinada pela Fundação Calouste Gulbenkian, 2004, pp. 337-348. 
Carol

A' colour-cleid thy snaw-white state,

Virgin inviolate!

In Bethlehem, toon o' luve's delicht, Born was the rose's blossom bricht!

Virgin inviolate!

In Bethlehem, toon o' luve's repose,

Born was the bricht rose-gairden's rose!

Virgin inviolate!

Born was the rose's blossom bricht:

Our Saviour Christ, oor Lord an' Licht!

Virgin inviolate!

Born was the bricht rose-gairden's rose:

True God, to be true Man Wha chose!

Virgin inviolate!

(Simpson, 1934: 45.)

In fact, Aubrey Fitz Gerald Bell (1881-1950) is probably still the person who has done most to disseminate Gil Vicente's works, laying the foundations of much of the scholarship that followed and whose own combination of hard work and erudition should not be underestimated (see Buchanan, 1953: 15-20). In 1918, Bell published the Auto da Alma in Portuguese with English translation in the Modern Language Review, then in 1920, Four Plays of Gil Vicente, with Portuguese and English versions of the Auto da Alma, Exhortação de Guerra, Farsa dos Almocreves and Tragicomedia Pastoril da Serra da Estrela. 1929 saw the publication of his translations of the Auto da Barca do Inferno, Auto da Barca do Purgatório and the Auto de la barca de la gloria, the first two from the Portuguese and the third from Spanish. Bell's translations are marked by their explicitly disseminatory function and 
characterised by a very English poetic diction in which end rhyme is achieved by judicious selection of lexical items, amplification and explicitation:

FrIAR God bless my soul! There is no knowing What'll happen next; I stand aghast.

Devil Let us not tarry here unduly Step on board, we must be going: You'll have two oars to do the rowing.

FRIAR That's not in the agreement, truly

Devil Sentence on you is long since passed.

(Gerald [Bell], The Ship of Hell, 1929: 29.)

Although they may seem somewhat 'dated' since they were first published, they still serve to introduce the English-speaking reader to the theatre of Gil Vicente, and in some cases are the only English versions available. In addition, several of his works on Portugal (see bibliography) include fragments from the Floresta de Enganos, Auto de Mofina Mendes, O Clérigo da Beira, O Juiz da Beira, Quem Tem Farelos? and Romagem dos Agravados.

In respect of the Vicentine lyrics, Bell's Poems from the Portuguese (With the Portuguese Text, 1913) contains translations of 4 Vicentine poems. In the following year, he published Lyrics of Gil Vicente with the Portuguese Text (54 poems), then in 1921 a second edition now with the shorter title of Lyrics of Gil Vicente, a lengthier introduction, and 51 poems; some poems have been dropped, but others have been included (and reprinted in 1925). Bell was conscious of the multiple possibilities open to the translator, and believed that once made, a translation is not fixed for all time, but can be reworked, perhaps improved, therefore in some cases he published several different versions of the same poem.

Generations of translators have followed in Bell's footsteps, producing their versions of Vicente's poems for English language readers. A survey of printed and on-line sources reveals that the most translated lyrics derive from Castilian source texts. Thus, from the Auto de la Sibila Casandra: 'Muy graciosa es la doncella', has 29 English translations; 'Dicen que me case yo', 
15; 'Sañosa está la niña'. 10; 'En la huerta nasce la rosa' (Auto dos Quatro Tempos), 10; 'Si dormís, doncella' (Quem Tem Farelos?), 10.5

It seems only right that poems composed to be sung should reach an English-speaking readership or audience through the musical route. Consequently, lyrics have been translated by and for those whose principal interest lies in the musical aspect of Gil Vicente. For example, 'Mal haya quien los envuelve', Auto dos Quatro Tempos, was translated into German by Paul Heyse and set to music by Hugo Wolf, becoming no. 33 of the Spanisches Liederbuch: Weltliche Lieder, 1889-1890. While this is not new information - see Albin Beau's study of Gil Vicente in German (1939) - scholars may be not be aware that certain Vicentine lyrics have subsequently been translated into English for those who do not wish to sing their Lieder in German. Thus we have musical scores with English translations by John Bernhoff, among others. 1939 saw the appearance of the 'Shepherd's Song or Vilancete, Portuguese words by Gil Vicente, free English version by Sheila Power'. Dating from 1951, included in the musical score by Juan Orrego Salas, Canciones castellanas, we find 'They'd have me get married, oh!' ('Dicen que me case yo') and 'Oh, where do I cross these ranges?' ('Por do pasaré la sierra'), translated by Norman Fraser. In 1967, Eugene S. Butler published 'As beautiful as she. Three part men's voices T. B. B. Poem by Gil Vicente'. New audiences continue to 'discover' Gil Vicente's lyrics, especially the audiences that routinely expect to find English translations on the Internet and their CD inserts. For instance, one website entitled LiedNet Archive has the German translations of Emanuel Geibel with English translations by David K. Smythe. ${ }^{6}$ In fact, it might be possible to explore other translations in the context of a study of the discography of Gil Vicente's lyrics. 'Si dormis, doncella', from Quem Tem Farelos?, has become part of the English repertoire as 'Art thou sleeping maiden?' because it has been set to music. ${ }^{7}$ Finally, at least 93 lyrics have been translated, either as stand-alone poems, or as part of the play in which they are embedded, by numerous translators

5 Numbers based on this author's own research findings.

6 Emily Ezust, LiederNet Archive, http://www.lieder.net/lieder/

7 The most recent known stand-alone poem translations are owed to John Howard Reid (2010). 
who have produced their own version of a poem that they deem worthy of attention and appreciation.

Regarding the full-length plays, these have been translated for vastly different reasons and in very diverse contexts: because of their religiosity, literary and dramatic merits, sociological or linguistic interest, or even in partial fulfilment of the requirements for a doctoral thesis (Arney, 1969; Smolen, 1990; MacLaren, 1999). McLaren not only produced reading versions of A Farsa de Inês Pereira and Quem Tem Farelos? in standard English, but a second pair of translations in Glasgwegian Scots, where the performative function is paramount. The English versions remain close to the source texts, although this translator did seek a solution to Gil Vicente's ambiguous treatment of Jewish characters in the Farsa de Inês Pereira. Her solution was to retain the Jewish matchmakers in her standard English text, only removing those references which she believed could cause offence, replacing them altogether with non-Jewish characters in the performance text.

The Auto da Barca do Inferno in particular has proved popular with several generations of translators (see list below), perhaps because of its relevance for comparatists who have traced the similarities with the Medieval English morality play ${ }^{8}$ and possible sources such as the Dance of Death ${ }^{9}$ - or because of the light it sheds on sixteenth-century Portuguese society through the characters 'strutting and fretting their hour upon the stage'.

Certain plays, notably the Exortação da Guerra and Auto da Índia, have attracted attention because of their pertinence for students of Portuguese History and the Discoveries (Lappin, 1997; Raman, 2004: 15-31), while the emergence of Women's Studies has stimulated interest in works such as the Comédia de Rubena, Inês Pereira and the Auto de la Sibila Casandra. This latter work has a long (pre-feminist) translation history that began in 1929 when John Brande Trend published an abridged version, The Mystery of the Sibyl Cassandra, perhaps not widely known because it appeared in the journal Music \& Letters. Trend's motivation making the translation was to

8 Fernando de Mello Moser, Discurso Inacabado. Ensaios de Cultura Portuguesa. Lisbon: Fundação Calouste Gulbenkian, 1994.

9 See José Augusto Cardoso Bernardes, 'Danças da Vida e da Morte nas Barcas de Gil Vicente', eHumanista: 1, 2001, 12-27. 
provide the basis for a performance of the nativity play, and especially of the songs, set to music from the Cancionero del Palacio in the Royal Library, Madrid, printed in 1890 by Barbieri. Since then, the emphasis on performance has been a constant: on 19/01/1951 the BBC Third Programme (radio) broadcast the Auto de la Sibila Casandra A Christmas mystery play first played in 1513 in the presence of Queen Lianor of Portugal performed in Spanish and produced by Emilio Blázquez-Dávila, of the Latin-American Service of the BBC). ${ }^{10}$ Eight years later the BBC broadcast The Sailor's Wife and The Widower's Comedy (09/11/1959) in Jill Booty's performance-oriented translation. ${ }^{11}$ (She also translated Quem Tem Farelos? and Auto dos Reis Magos, publishing the four works in 1961).

In fact, the focus on performance has introduced another dimension to Vicentine Studies. The last two decades have seen a significant upsurge of interest in the performance — and performability — of Golden Age plays in translation, led by David Johnston and others interested in bridging the gap between academia and the theatrical world, as well as eliminating what Johnston has termed 'philological deadness' (Johnston, 2009: 57). Adopting this approach, in 1994 Johnston merged, condensed and adapted the three Boat Plays for staging at London's Gate Theatre. The performances, in December 1994 and January 1995, were highly successful, but unless read with caution, the published version of this very free adaptation (1997) may present problems for the unwary reader. The 'leitor avisado', on the other hand, will be disconcerted by Johnston's changes to the original plays, cutting out some of Vicente's characters (page boy, cobbler, Jew) and adding in others (Gil Vicente himself, prince, courtiers). Many of the speeches are deleted and replaced with lines of his own invention. From a dramatic point of view, they are eminently performable, though sometimes closer to pantomime than morality play:

This fool shouldn't be here for a week yet.

Still, if I can lure him into my net...

10 http://genome.ch.bbc.co.uk/73ef746bbdb1498587a497066a3d1199

11 http://genome.ch.bbc.co.uk/128509c890c642e1819891dfdd7524c7 
though I do wish he'd speak in longer lines,

it's such a strain to think of the rhymes.

(Johnston, 1997: 32.)

However, we should also note the presence of intertextual allusions alongside the comic elements, as demonstrated by the character Gil Vicente's intertextual speech at the beginning of The Boat to Purgatory:

Life is but a dream;

and death the final awakening,

never more to sleep.

(Johnston, 1997: 46.)

The history of Gil Vicente in English translation inevitably sheds light on the history of theatre translation in general, revealing a spectrum of options ranging from the 'faithful' or literal to the speakable/performable. As a matter of interest, Roy Campbell seems to be the natural successor to Bell, as can be seen in his rendering of 'Remando vão remadores':

Rowing go the rowers

In a ship of great delight.

The captain at the helm

The Son of God is Light.

Angels at the oars

Rowed with all their might.

The flag of hope was flying

Lovely to the sight.

The mast was of endurance

Like crystal shining bright.

The sails were stitched with faith

And filled the world with light.

The seashore was serene

With not a wind in flight.

(Campbell, 1957: 132.) 
This translation relies on rhyme, rhythm and strong religious symbolism in equal parts; indeed, Campbell's rather 'muscular' translation reminds the reader of such rousing hymns as Onward Christian Soldiers or even the traditional English sea shanty. David Johnston, on the other hand, transforms an allegorical poem into something with reminiscences of the negro spiritual and the Christmas carol:

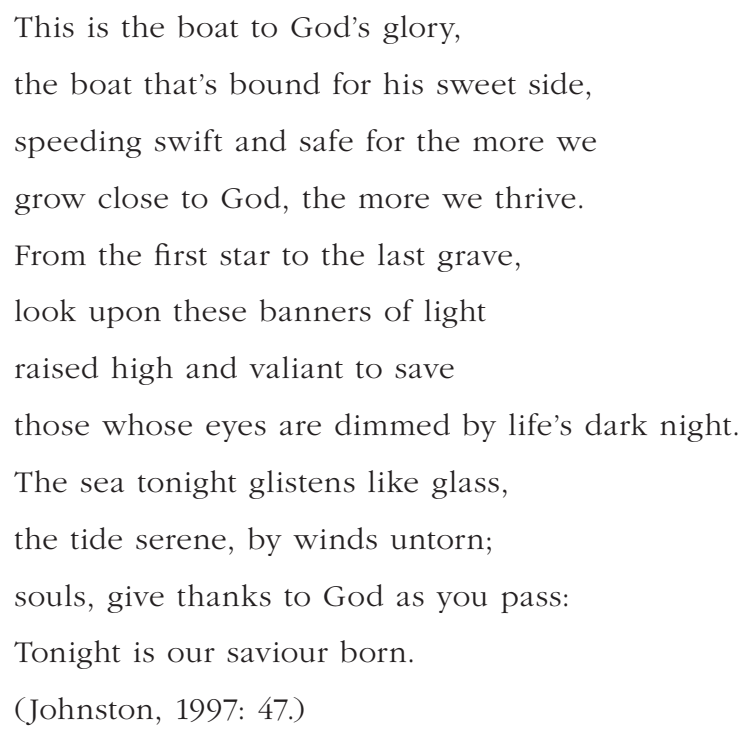

The twenty-first century has also seen translations of Vicentine plays for the stage. In 2000, Cheryl Folkins McGinniss published her version of the Auto de la Sibila Casandra, under the lengthy title of The Sibyl Cassandra. A Christmas Play with the Insanity and Sanctity of Five Centuries Past. This translation reads well and could, as intended, serve as the script for a nativity play, although the critical apparatus is not of the same standard. McGinniss and two co-authors have also published an article (2005) discussing the performance and reception of this play.

In August 2003 an undergraduate cast of actors from the University of Oxford performed, One in the Street, the Other in the Bed. Auto da India and Inês Pereira, in Oli Henman's adaptation from Lappin's and MacLaren's translations respectively, staged in the Greenwich Theatre, London. 
More recently, the collaborative research project Out of the Wings: Spanish and Spanish American Theatres in Translation (2008-2011), involving academics Catherine Boyle and David Johnston among others, aimed 'to make the riches of the theatres of Spain and Spanish America accessible to English-speaking researchers and theatre professionals' through a virtual environment (online data base). ${ }^{12}$ Kathleen Jeffs prepared the entry for Gil Vicente, and has uploaded the relevant staging information and production history for Jo Clifford's translation Dom Duardos 2010). ${ }^{13}$ She also provides contextual matter and excerpts from her translation of The Sibyl Cassanda (2011). ${ }^{14}$ In addition, Jeffs has published an extremely useful article with information about the genesis of Clifford's adaptation of Dom Duardos, $a$ detailed analysis of the translation itself as well as information about a staged reading held in Oxford in 2010 (Jeffs, 2012: 232). The article also contains extracts from Clifford's unpublished translation of this play, which still awaits its first performance.

To conclude, our research has revealed the extent of Gil Vicente's projection in the English-speaking world. Scholars may lament the fact that many of his works remain beyond the reach of those without a reading knowledge of Portuguese (or Spanish), nevertheless translations of Gil Vicente's works are available, propelling his drama into the spotlight; there is undeniable truth in the affirmation that translation gives a work an afterlife. That Gil Vicente continues to be translated and performed in the twenty-first century, is a testimony to the enduring appeal of his plays and songs more than five centuries after they were first written. Since literary or theatre translation is always a work in progress, there is no terminus ad quem for new English-language versions of Vicente's lyrics or plays. ${ }^{15}$ It is only to be hoped that future translators will tackle plays that have not so far been translated into in English, making more of his works available to students, scholars and actors.

12 http://www.outofthewings.org/theatres/goldenage/

13 http://www.outofthewings.org/db/play/don-duardos/sample-translations Don Duardos, considered by many to be one of Vicente's best plays, has not yet been published in book form.

14 http://www.utofthewings.org/db/play/la-sibila-casandra/translations

15 The most recent stand-alone poem translations are owed to John Howard Reid and were published in 2010 . 


\section{Play translations, COMPlete or PARTial}

Auto da Alma

1916. George Young, Auto da Alma, in Portugal, An Anthology, pp. 73-77. Excerpt.

1918. Aubrey F. G. Bell, The Soul's Journey, Modern Language Review, XIII: 1 , pp. 58-77.

1920. Aubrey F. G. Bell, The Soul's Journey, in Four Plays, pp. 1-21.

1972. A. R. Barter, Auto of the Soul, Portugal through her literature..., p. 126. Excerpt.

Auto da Barca do Inferno

1916. George Young, Portugal, An Anthology, pp. 65-70. Abridged.

1929. A. F. Gerald (Aubrey F. G. Bell), The Ship of Hell, The Ship of Purgatory, The Ship of Heaven, pp. 17-43.

1957. Roy Campbell, Auto da Barca do Inferno, in Portugal, pp. 131-132. Excerpt.

1996. D. Johnston, The Boat Plays. Auto da Barca do Inferno, Auto do Purgatório, Auto da Embarcação da Glória. Bath. Absolute Press.

1997. Anthony Lappin, Auto da Barca do Inferno, in Three Discovery Plays, pp. 1-113.

Auto da Barca do Purgatório

1929. A. F. Gerald (Aubrey F. G. Bell), The Ship of Hell, The Ship of Purgatory, The Ship of Heaven, pp. 45-70.

1996. D. Johnston, The Boat Plays. Auto da Barca do Inferno, Auto do Purgatório, Auto da Embarcação da Glória. Bath. Absolute Press.

Auto da la embarcación de la gloria

1929. A. F. Gerald (Aubrey F. G. Bell), The Ship of Hell, The Ship of Purgatory, The Ship of Heaven, pp. 71-98.

1996. D. Johnston, The Boat Plays. Auto da Barca do Inferno, Auto do Purgatório, Auto da Embarcação da Glória. Bath. Absolute Press. 


\section{Auto da Feira}

1823. Thomas Roscoe, in J.-C.-L. Simonde de Sismondi, Historical View of the Literature of the South of Europe. Vol. 4. London: Printed for Henry Colburn and Co. (Reference taken from the third edition, London: Henry Bohn, vol. II, 1850, pp. 542-543). Excerpt.

1915. Aubrey Bell, in Portugal of the Portuguese, pp. 155-156.

1916. George Young, in Portugal, An Anthology, pp. 123-125.

\section{Auto da Índia}

1961. Jill Booty, The Sailor's Wife, The Tulane Drama Review, vol. 5, No. 3. (March), pp. 171-178.

1997. Anthony Lappin, Auto da Índia, in Three Discovery Plays, pp. 114-167.

\section{Auto da Lusitânia}

1957. Roy Campbell, Auto da Lusitânia, in Portugal, pp. 129-131. Excerpt.

Auto dos Reis Magos

1961. Jill Booty, The Three Wise Men, The Tulane Drama Review, vol. 5, No. 3. (March.), pp. 161-164.

\section{El auto de la Sibila Casandra}

1921. Georgiana Goddard King, The Play of the Sibyl Cassandra. Pennsylvania: Bryn Mawr College; New York, Bombay, Calcutta, and Madras: Longmans, Green and Co.

1929. John Brande Trend, 'The Mystery of the Sibyl Cassandra', Music E Letters, 10:2 (April), pp. 124-140. Abridged.

1969. Ann Adele Arney, The Play of the Sibyl Cassandra. Submitted in Partial Fulfilment of the Degree of Master of Arts in the Department of English, University of South Carolina.

2000. Cheryl Folkins McGinniss, The Sibyl Cassandra. A Christmas Play with the Insanity and Sanctity of Five Centuries Past. Gil Vicente. Introduction and Lanham, New York, Oxford: University Press of America, Inc.

2005. Robert Potter, 'La Sebila Casandra: Gil Vicente's Postmodern Feminist Christmas Play', European Medieval Drama, 9, pp. 109-126. Excerpts. 
2010. Kathleen Jeffs, La Sibila Casandra, Out of the wings website, at: http://www.utofthewings.org/db/play/la-sibila-casandra/translations Last accessed March 2017.

Comédia de Rubena

1993. Jack E. Tomlins, The Play of Rubena. Gil Vicente. A verse translation by Jack E. Tomlins. Edited, with an introduction, by René P. Garay and José I. Suárez. New York: National Hispanic Foundation for the Humanities.

\section{Comédia do Viúvo}

1961. Jill Booty, The Widower's Comedy, The Tulane Drama Review, vol. 5, No. 3. (March), pp. 178-186.

\section{Ex(b)ortação da Guerra}

1917. George Young, Portugal, An Anthology, pp. 35-47. Abridged.

1920. Aubrey F. G. Bell, Exhortation to War, in Four Plays, pp. 23-35.

1972. A. R. Barter, 'Exhortation for war', Portugal through her literature..., p. 127. Excerpt.

1997. Anthony Lappin, Exortação da Guerra, in Three Discovery Plays, pp. $160-213$.

\section{Farsa de Inês Pereira}

1972. A. R. Barter, 'Inês Pereira', Portugal through her literature..., p. 123. Excerpt.

1999. Ann MacLaren, Page and Stage: Translation and Transformation for Gil Vicente's New Audience. PhD. University of Glasgow, 1999. http://theses. gla.ac.uk/6921/

Farsa dos Almocreves

1920. Aubrey F. G. Bell, The Carriers, in Four Plays, pp. 37-53.

Floresta dos Enganos

1915. Aubrey Bell, in Portugal of the Portuguese, pp. 153-156. Excerpt. 
Mofina Mendes

1915. Aubrey Bell, in Portugal of the Portuguese, pp. 159-160. Excerpt.

O Clérigo da Beira

1915. Aubrey Bell, in Portugal of the Portuguese, p. 160. Excerpt.

O Juiz da Beira

1915. Aubrey Bell, in Portugal of the Portuguese, p. 161. Excerpt.

Quem Tem Farelos?

1915. Aubrey Bell, in Portugal of the Portuguese, pp. 160-161.

1961. Jill Booty, The Serenade, The Tulane Drama Review, vol. 5, No. 3. (March), pp. 161-164.

1990. Marian Leanna Smolen, Who Has Bran? Appendix to Bilingualism as Semiotic Code in the Theatrical Code Systems of the Theater of Gil Vicente. Doctoral Thesis. Arizona State University, pp. 144-166.

1999. Ann MacLaren, Page and Stage: Translation and Transformation for Gil Vicente's New Audience. Doctoral Thesis. University of Glasgow. http://theses.gla.ac.uk/6921/.

Romagem dos Agravados

1915. Aubrey Bell, in Portugal of the Portuguese, pp. 156-159. Excerpt.

\section{Tragicomédia de Dom Duardos}

1992. Jo Clifford, Don Duardos. Extracts from unpublished translation, available at: http://www.outofthewings.org/db/play/don-duardos/sample-translations\#sa78-61 Last accessed March 2017.

Tragicomédia Pastoril da Serra da Estrela

1916. George Young, Portugal, An Anthology. 49-53. Excepts.

1920. Aubrey F. G. Bell, Pastoral Tragicomedy of the Serra da Estrella, in Four Plays, pp. 55-83. 


\section{PRIMARY SOURCES}

Anon (1846), 'Ancient Portuguese Drama', Quarterly Review, pp. 168-199.

Arney, Ann Adele (1969), The Play of the Sibyl Cassandra. Submitted in Partial Fulfilment of the Degree of Master of Arts in the Department of English, University of South Carolina.

Barter, A. R. (1972), Portugal through her literature: an anthology of prose and verse with introduction, notes on authors, and parallel translations. Glastonbury, Somerset: Walton Press.

Bell, Aubrey F. G. (1912), In Portugal. New York, London: John Lane.

- (1913), Poems from the Portuguese (with the Portuguese Texts). Oxford: Blackwell.

- (1914), Lyrics of Gil Vicente. Oxford: Blackwell. [Second edition 1921 different in some respects from the previous edition; third edition, 1925, reprint of the second].

- (1915), Portugal of the Portuguese. London: New York: Charles Scribner's Sons.

- (1918), The Soul's Journey, Modern Language Review, XIII: 1, pp. 58-77.

- (1920), Four Plays of Gil Vicente. Edited from the editio princeps (1562), with Translation and Notes, by Aubrey F. G. Bell. Cambridge at the University Press.

Bernhoff, John (1889-1890), Translation of Gil Vicente in Spanisches Liederbuch: Weltliche Lieder.

Booty, Jill (1961a), The Three Wise Men, The Tulane Drama Review, vol. 5, No. 3. (March), pp. 161-164 .

- (1961b), The Sailor's Wife, The Tulane Drama Review, vol. 5, No. 3. (March), pp. 171-178.

- (1961c), The Widower's Comedy, The Tulane Drama Review, vol. 5, No. 3. (March), pp. 178-186.

- (1961d), The Serenade, The Tulane Drama Review, vol. 5, No. 3. (March), pp. 161-164.

Bouterwek, Frederick (1823), History of Spanish and Portuguese Literature. In two volumes. Translated from the original German by Thomasina Ross. Vol. II. Portuguese Literature. London: Boosey and Sons.

Bowring, John (1824), The Ancient Poetry and Romances of Spain. London: Taylor and Hessey.

Campbell, Roy (1957), Portugal. London: Max Reinhardt.

Clifford, Jo (no date), Don Duardos. Extracts available at: http://www.outofthewings.org/db/play/ don-duardos/sample-translations\#sa78-61. Last accessed Match 2017.

Geibel, Emanuel \& Paul Heyse (1852), Spanisches Liederbuch. Berlin: Verlag von Wilhelm Herz (Bessersche Buchhandlung). [Third edition 1904].

Gerald, A. F. [Aubrey Bell] (1929), The Ship of Hell, The Ship of Purgatory, The Ship of Heaven. Watford: Voss \& Michael.

Jeffs, Kathleen (2010), Auto de la Sibila Casandra. Excerpts available at: http://www.outofthewings. org/db/play/don-duardos/sample-translations Last accessed March 2017.

Johnston, D. (1996), The Boat Plays. Auto da Barca do Inferno, Auto do Purgatório, Auto da Embarcação da Glória. Bath. Absolute Press.

King, Georgiana Goddard (1921), The Play of the Sibyl Cassandra. Pennsylvania: Bryn Mawr College; New York, Bombay, Calcutta, and Madras: Longmans, Green and Co.

Lappin, Anthony (1997), Three Discovery Plays. Warminster. Aris \& Phillips.

MacLaren, Ann (1999), Page and Stage: Translation and Transformation for Gil Vicente's New Audience. Doctoral Thesis. University of Glasgow. http://theses.gla.ac.uk/6921/ Last accessed March 2017.

McGinniss, Cheryl Folkins (2000), The Sibyl Cassandra. A Christmas Play with the Insanity and Sanctity of Five Centuries Past. Gil Vicente. Introduction and Lanham, New York, Oxford: University Press of America, Inc. 
Potter, Robert (2005), 'La Sebila Casandra: Gil Vicente's Postmodern Feminist Christmas Play', European Medieval Drama, 9, pp. 109-126.

Reid, John Howard (2010), A Salute To Spanish Poetry: 100 Masterpieces from Spain E Latin America rendered into English verse. Amazon print.

Roscoe, Thomas (1823), in J.-C.-L. Simonde de Sismondi, Historical View of the Literature of the South of Europe. Vol. 4. London: Printed for Henry Colburn and Co., 1823. [Citations from the third edition, London: Henry Bohn, vol. II, 1850, pp. 542-543.] Excerpt.

Simpson, Margaret Winefride (1934) The Wind's Heart. Edinburgh and London: The Moray Press.

Smolen, Marian Leanna (1990), Who Has Bran? Appendix to Bilingualism as Semiotic Code in the Theatrical Code Systems of the Theater of Gil Vicente. Doctoral Thesis. Arizona State University, pp. 144-166.

Tomlins Jack E. (1993), The Play of Rubena. Gil Vicente. Edited, with an introduction, by René P. Garay and José I. Suárez. New York: National Hispanic Foundation for the Humanities.

Trend John Brande (1929), 'The Mystery of the Sibyl Cassandra', Music E Letters, 10:2. (April), pp. 124-140.

Young, Sir George (1916), Portugal, An Anthology. Oxford: Oxford University Press.

\section{SECONDARY SOURCES}

Beau, Albin Eduard (1939), Gil Vicente na Alemanha. Coimbra: Instituto Alemão. Separata.

Buchanan, M. A. (1953), 'Aubrey Fitz Gerald Bell', in Harold V. Livermore (ed.), Portugal and Brazil. An Introduction made by Friends of Edgar Prestage and Aubrey Bell in Memoriam. With the assistance of W. J. Entwistle. Oxford: At the Clarendon Press, pp. 15-20.

Jeffs, Kathleen (2012), 'Prolonging the Pleasure: Gil Vicente and Jo Clifford's Adaptations of Don Duardos for Ever-New Audiences', in Javier Muñoz-Basols, Catarina Fouto, Laura Soler González, Tyler Fisher (eds.), The Limits of Literary Translation: Expanding Frontiers in Iberian Languages. Kassel: Reichenberger, pp. 229-252.

Johnston, D. (1996), Stages of Translation. Bath: Absolute Classics.

- (2009), 'Historical Theatre: The Task of the Translator', TRANS, 13, pp. 57-70.

- (2012), Translating the Theatre of the Spanish Golden Age: A Story of Chance and Transformation. London: Oberon.

McGinniss, Cheryl Folkins, Cecilia McGinniss Kennedy \& Charlotte Louise McGinnis (2005), 'The Relationship of Bride and Bereaved: A Trilogy for Contemporary Performance of Works by Gil Vicente and Lucas Fernández', Hispanófila, No. 144 (May), pp. 1-16.

Odber de Baubeta, P. A. (2001), 'The Sir Henry Thomas Project: Towards A History of Portuguese Literature in English Translation', Actas do I Congresso Internacional de Estudos AngloPortugueses. Universidade Nova de Lisboa, 6-8 May 2001. Lisbon: Universidade Nova de Lisboa, Centro de Estudos Anglo-Portugueses, Faculdade de Ciências Sociais e Humanas, pp. 653-661.

_ (2001), 'The Sir Henry Thomas Project: Towards A History of Portuguese Literature in English Translation', Revista de Estudos Anglo-Portugueses, 10, pp. 43-65.

__ (2003a), 'Gil Vicente in English Translation', in Gil Vicente 500 Anos depois — Actas do Congresso Internacional Realizado pelo Centro de Estudos de Teatro da Faculdade de Letras da Universidade de Lisboa. 2 volumes. Lisbon: Imprensa Nacional-Casa da Moeda (Temas Portugueses), vol. II, pp. 291-306. 
__ (2003b), 'Translating Gil Vicente: Proverbs and Refrains', in Maria Fernanda Abreu, Maria Idalina Resina Rodrigues \& Maria Leonor Machado de Sousa (eds.), Em Louvor da Linguagem. Homenagem a M. Leonor Buescu. Lisbon: Edições Colibri, pp. 327-349.

_ (2004), 'A Vicentine Canon in Translation: The Celtic Connection', in Aires A. Nascimento, Helena C. Langrouva, José V. de Pina Martins and Thomas F. Earle (eds.), Humanismo para o Nosso Tempo. Estudos de Homenagem a Luís de Sousa Rebelo. Lisbon: edição patrocinada pela Fundação Calouste Gulbenkian, pp. 337-348.

_ (2007), 'A Poem for all Seasons', in Rhian Davies and Anny Brooksbank-Jones (eds.), The Place of Argument. Essays in Honour of Nicholas Round. In London: Tamesis, pp. 161-178.

- (2008), 'Women and Literary History in the $19^{\text {th }}$ Century', in Maria Leonor Machado de Sousa (ed.), A Guerra Peninsular. Perspectivas Multidisciplinares. Congresso Internacional $e$ Interdisciplinar Evocativo da Guerra Peninsular. XVII Colóquio de História Militar nos 200 Anos das Invasões Napoleónicas em Portugal. Actas. Vol. II. Lisbon: Comissão Portuguesa de História Militar \& Universidade Nova de Lisboa, Centro de Estudos Anglo-Portugueses, pp. $559-566$.

Power, Sheila (1939), Vilancete. A Shepherd's Song. With Portuguese Words by Gil Vicente. Free English Version by Sheila Power. London: Augener.

Raman, Shankar (2004), "The Ship Comes Well-Laden': Court Politics, Colonialism, and Cuckoldry in Gil Vicente's Auto da Índia' (2004), in E. Sauer and B. Rajan (eds.), Imperialisms. Historical and Literary Investigations, 1500-1900. New York: Palgrave Macmillan, pp. 15-31. 